\title{
Solid Particle Emission Abatement from Biomass- Fired Boilers in District Heating Plants
}

\author{
Egils Dzelzītis ${ }^{1}$, Aldis Jēgeris ${ }^{2}$, Agnese Līckrastinaa ${ }^{3}$, Normunds Talcis ${ }^{4}$, \\ ${ }^{1,3}$ Riga Technical University, ${ }^{2,4}$ DHC "Rigas siltums"
}

\begin{abstract}
Biomass combustion technologies have undergone rapid development during the last decades to become environmentally friendly. In order to evaluate the particulate matter formation and emission into the atmosphere, the measurements have been done in three wood biomass mediumscale district heating plants using different combustion technologies and various types of particle abatement equipment. The study shows similar solid particle formation in the boilers if they are operated at full load and favorable combustion conditions. The abatement units properly operated can reduce the particle emissions down to $40 \%$ from the maximum calculated limit.
\end{abstract}

Keywords - biomass, district heating plant, particulate formation, particulate abatement

\section{INTRODUCTION}

The strong environmental requirements and EU decision to decrease the share of the imported fuels in the Europe's energy balance promotes the utilization of the local energy resources in combination with the best practice of the environmental protection technologies. The European Union has set the target to increase the share of the renewable energy in the total energy balance to $20 \%$ until the year 2020 [13].

Biomass combustion technologies have undergone rapid development during the last decades. Biomass fuels are considered $\mathrm{CO}_{2}$ neutral. At the moment, biomass combustion systems have achieved low carbon monoxide and low nitrogen oxides emission levels [12]. The main disadvantage of the biomass combustion is ash related problems requiring particular attention to the fly ash emissions into the surrounding air. Ash formation leads to the decreased efficiency of the biomass boilers as well to the operation problems due to corrosion, slagging and deposit formation.

Wood and wood residues compose the greatest share among local renewable fuels in Latvia thus becoming a very attractive and sustainable alternative even in large district heating systems.

The solid particle formation from the combustion devices and their further emission into the atmosphere could be reduced in two ways. The primary measures consider the elimination of particle formation during the combustion process while the secondary measures are used to reduce the amount of solid particles after they leave the furnace. Industrial boilers are typically adapted to the optimal combustion regimes thus avoiding the particle formation caused by incomplete combustion. For medium to large scale applications the particulate abatement after the combustion chamber are required for further decrease of the amount of particulate matter. [2].

According to the Latvian regulations, the allowable emission limit for particulate matter emissions from the boiler plants with installed heat capacity from 10 up to 50 MW fuelled by solid fuels or wood chips should be below 500 $\mathrm{mg} / \mathrm{m}^{3}$ at the oxygen amount in the flue gasses $6 \%$ [17].

\section{ASH FORMATION DURING BIOMASS COMBUSTION}

Particle formation is influenced by the fuel properties, combustion conditions, appliances, excess air and boiler load [13]. It is caused by the inorganic substituents initially present in the fuel and originated both during complete and incomplete combustion. The amount of soot and organic particles originating during incomplete combustion is typically very low for medium and large scale biomass boilers. The optimal combustion conditions and long residence time in the combustion zone prevent particle formation caused by variable and unstable combustion process. Ash formation is caused by minerals present in the fuel and it cannot be avoided by optimising the combustion appliances. The only possibility to reduce ash emissions from the biomass combustion units is by particle abatement technologies.

All inorganic particles originated during the complete combustion are divided into two large groups. The large particles form bottom ash are carried away from the combustion zone by ash conveyor. The smaller particles are taken by flue gases. The latter is called fly ash and has to be paid particular attention in the operation of biomass combustion units.

Flue gas purifying is first and foremost the question of reducing the amount of fly ash emitted through the stack. Concentration of fly ashes depends on the ash content in the fuel and the load of the combustion unit [9]. The fly ash itself could be divided into two groups. The particles larger than some micrometers are called coarse fly ash. The high flow rates in the industrial boilers lead to the situation when the smallest part from the ash and char residues are taken by the flue gas and form the coarse fraction of the fly ash. Due to that the coarse portion of the fly ash in the biomass boilers is typically high [15]. Particles smaller than 1 micrometer are called fine fly ash or aerosols. The formation pathways of the coarse fly ash and fine fly ash are different. Also their chemical composition and behavoiur are different and therefore they are usually treated separately [12].

The fly ash is defined as particulate matter (PM) and is characterized by the size of the particles. The fly ash from the 
combustion of wood is set for the total amount of solid particles, for $\mathrm{PM}_{10}$ and $\mathrm{PM}_{2.5}$. Particular attention in biomass combustion is paid to the formation of $\mathrm{PM}_{10}$, describing particles with aerodynamic diameter less than 10 micrometers. This would include both coarse and fine particles. Attention should be also paid to $\mathrm{PM}_{2.5}$, i.e. the particles with the diameter less than 2.5 micrometers [21]-[23].

The chemical properties of biomass and the chemical composition of biomass ashes vary. Wood bark has the highest ash content while the ash concentration for wood chips varies depending on the type wood and the presence of bark and of inorganic materials like sand and stones. According to the data collected in [7], the mass concentration of fly ash particles behind the boiler is in the range of $60-3000 \mathrm{mg} / \mathrm{nm}^{3}$. The major part of wood ash is typically composed of calcium $(\mathrm{Ca})$ and potassium $(\mathrm{K})$, part of which volatilizes during the combustion and forms fine particles [11].

Wood bark typically has high ash content with comparatively high concentration of heavy metals ( $\mathrm{Zn}$ and $\mathrm{Cd}$ ) that are mainly recovered in the fly ash as they vaporize during the combustion. They often are found on the surface of fine fly ash particles or in the aerosols [12]. It is found in [16] that fine ash fraction from the woody biomass is typically formed by potassium sulphates, chlorides and carbonates.

There are usually three different types of biomass ashes considered in the plants. The bottom ash constitutes the major fraction and is characterized by the presence of sand, stones and earth. They lower the melting point thus causing slag formation. Cyclone ash is finer and consists of inorganic ash particles. This ash fraction is mainly composed by coarse fly ash. The filters, electrostatic precipitators and gas condensation units collect the finest fly ash particles. Normally it consists of aerosols [12].

The data shown in [14] give the general overview about the distribution among biomass ashes (see Table I). It shows that more than $60 \%$ from the total amount of ash is composed of coarse ash with the particle diameter more than $50 \mu \mathrm{m}$, while the fine ash constitutes from 2 to $20 \%$. There are large variations for the same type of biomass fuel characterizing the huge diversity of the constituents of the biomass.

TABLE I

MASS PERCENTAGE OF ASH FROM BIOMASS COMBUSTION (ADOPTED FROM [14])

\begin{tabular}{|l|c|c|c|}
\hline Particle size $(\boldsymbol{\mu m})$ & Fuel ash & Bark & Chipping \\
\hline$>\mathbf{5 0}$ & Coarse & $65-85$ & $60-90$ \\
\hline$<\mathbf{1 0}$ & Cyclone ash & $10-25$ & $50-70$ \\
\hline$<\mathbf{1}$ & Fine ash & $2-10$ & $10-20$ \\
\hline
\end{tabular}

\section{PARTICULATE ABATEMENT TECHNOLOGIES FOR BIOMASS BOILERS}

There are several particle abatement technologies most commonly used for the flue gases cleaning - cyclones, electrostatic precipitators and wet scrubbers, which are often used as flue gas condensers [3].

\section{A. Multicyclones}

Relatively large particles can be easily trapped by means of multicyclones. Multicyclones are often used for pre-cleaning of the flue gas before the flue gas condensation unit. [11].

All cyclones create the centrifugal force lowing downward in the vortex. Heavier particles from the flue gas repeatedly knock the wall and drop down. Several cyclones in a row form a multicyclone with one common inlet and outlet for air [6]. Each barrel has smaller diameter compared to the regular cyclones, thus leading to the greater amount of time for particles to be in the unit and to the larger dust removal efficiency. Multicyclones are known as simple-design units with low to moderate gas side pressure drop, inexpensive and working at a wide range of temperatures. The main disadvantages of multicyclones are low efficiency of small particle collection and lower total efficiency working at partload conditions [9], [14].

Cyclones are not among the most efficient technologies for reducing particles with the size smaller than $5 \mu \mathrm{m}$ [2]. A typical efficiency for cyclones is $55-99 \%$ for particles from $1.0 \mu \mathrm{m}$ to $100 \mu \mathrm{m}$, while the highest efficiency (90\%) is reached for the particles over $10 \mu \mathrm{m}$.

\section{B. Electrostatic precipitators}

The electrostatic precipitators (ESP) have the lowest efficiency for very fine particles between $0.1 \mu \mathrm{m}$ to $1.0 \mu \mathrm{m}$ of aerodynamic diameter. The collection efficiency of these types of dust is between $90 \%$ and $95 \%$. The proportion of so small particles in the total fly ash flow is small and has negligible impact on the collection efficiency.

ESP use the electrostatic charges to remove the particulates from the flue gas stream. The unit is composed of high voltage direct current negatively charged electrodes placed between the plates that are grounded and positively charged. Flue gas flows through the passages. Particulates receive the negative charge from the discharging electrodes and then get stuck to the collection plates, which are vibrating to remove the adhered particles.

Electrostatic precipitator is very efficient for very small particles. The disadvantage is sensitiveness for varying flow rates and amount of particles, as well as decreased efficiency during the operation [3].

Larger collective surface areas and lower flue gas flows through ESP lead to higher particle removal efficiency as dust particles have more time and surface to collect. The efficiency of large ESP units can reach more than 99\% [2]. Due to that ESP today is one of the most widely used technologies for modern heat and power generation plants [4].

\section{Flue gas condensers}

Flue gas condensers are often designed as wet scrubbers having double effect on the operation of the biomass boiler plant. They act as a particulate abatement technology ensuring capturing fine fly ash particles [10] and recovering the latent heat from the flue gas flow.

During the operation, the process water is injected into the flue gas condenser. The surface of small droplets absorbs fine 
fly ash particles and even gases from the flue gas flow simultaneously absorbing also heat from the gas stream. The surface area of the sum of all the droplets is large enough to ensure high efficiency for the absorption process.

The higher is the moisture content in the fuel, the larger amount of heat is carried by the flue gasses [14]. Recovering the latent heat significantly increases the boiler efficiency up to $30 \%$. The wood biomass moisture could reach even $55-60 \%$ of the moisture content thus making flue gas condensers an attractive option for the flue gas treatment in the biomass boiler plants [1].

\section{PARTiCUlate ABATEMENT IN BIOMASS BOILERS AT DHC RIGAS SILTUMS}

District heating company "Rigas siltums" has always been focused on environmental protection and sustainable and reliable heat production. Gas fired boiler plants are gradually enlarged with the wood chips boilers. Biomass became the main heat source for the district heating plants. The change of the fuel leads to the consequent change of the combustion technologies and the ways how the gaseous emissions are formed.

From the environmental protection point of view, the main difference between gaseous emission formation from natural gas combustion and biomass combustion is based on the formation of fly ash in the flue gas. The maximum allowed calculated limits for solid particle emissions for each boiler are set in the special permission by the Latvian environmental protection authority [18-20].

The combustion of biomass can be provided in either fixed bed or fluidized bed conditions. During the fixed bed combustion, the combustion air is supplied to the fuel from the bottom. It initiates drying and gasification of the biomass with the subsequent combustion of the char. To ensure complete and reliable fuel combustion, air supply is typically divided into two or three locations. Fixed bed systems are designed for biomass with the variable moisture content and variable fuel particle size [5].

In the fluidized bed furnace, the biomass is combusted in the suspension of gas, sand, fuel and ashes. Also in this case the primary air is supplied through the bottom of the bed. In the bubbling fluidized bed furnaces the bed material is located at the bottom of the furnace. Fluidized bed systems are flexible regarding fuel material, moisture content while they are sensitive to the fuel particle size [8], [5]

\section{A. Measurements}

Three district heating biomass-fired boiler plants with comparable installed heating capacities are considered in this study. Boiler plants have different combustion technologies. It was assumed that the combustion technology could influence the amount of solid particles originating during biomass combustion. The measurements are carried only in full load operation in order to avoid the influence of the part load conditions and incomplete burning of the biomass. It ensures that the particle formation mainly originates from the minerals initially present in the biomass.

All boiler plants are fuelled by wood chips delivered by the same company. Measurements are done behind the boiler and behind each of the flue gas cleaning units, i.e. behind the multicyclone, behind the electrostatic precipitator, and behind the flue gas condensing unit. Measurements were done during the last heating season by the licensed companies and only in actual operating conditions.

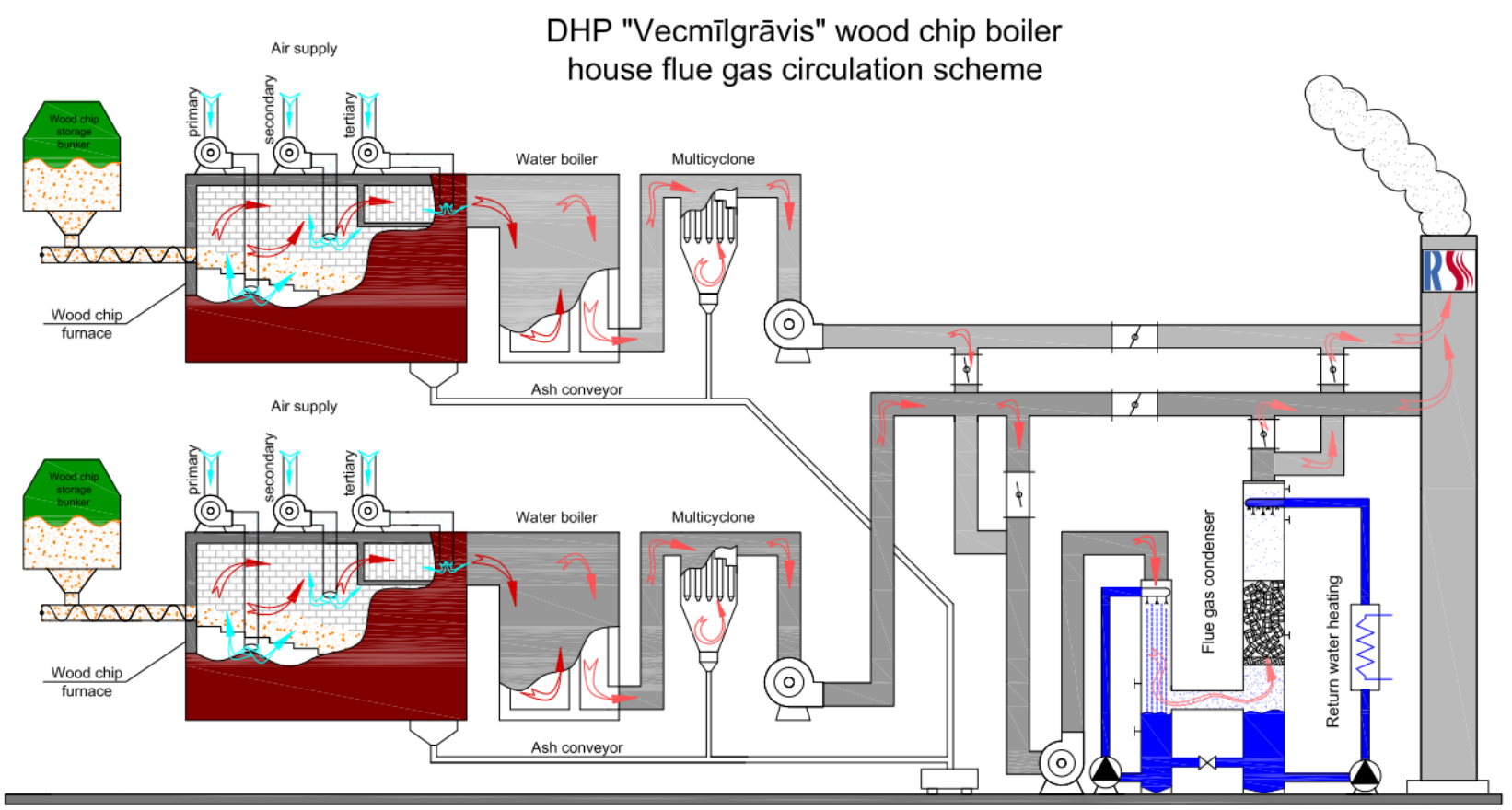

Fig. 1. Flue gas circulation scheme at DHP "Vecmilgravis". 


\section{B. District heating plant "Vecmilgravis"}

In 2010, wood-chips fired water heating boilers were installed in the district heating boiler plant "Vecmilgravis". In 2013 they were equipped with the flue gas condenser in order to increase the capacity of the boiler plant and decrease the particulate matter emitted through the stack. Now there are two hot water boilers AK-7000 with the total installed heating capacity 14 MW (Fig.1). Both boilers are equipped with moving grate pre-furnace, hot water boilers with the multicyclone. The flue gas condenser is located after the multicyclone for further decrease of the particulate emissions.

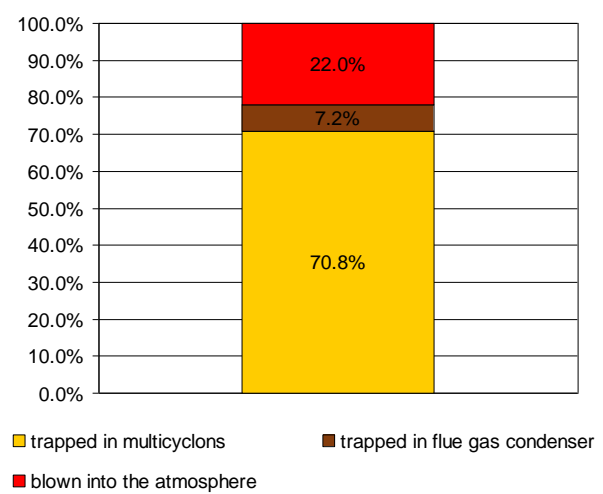

Fig. 2. Particulate matter originated in the biomass boilers at DHP "Vecmilgravis" trapping distribution in the flue gas cleaning devices.

The measurements have been done behind the boiler in order to evaluate the amount of particulates originated during the combustion. The next measuring point is located behind the multicyclone and the third - behind the flue gas condenser. The maximum permitted amount of particulate emissions leaving the boiler plant could reach $77 \mathrm{mg} / \mathrm{nm}^{3}$ for $\mathrm{PM}_{10}$ and the $42 \mathrm{mg} / \mathrm{nm}^{3}$ for $\mathrm{PM}_{2.5}$ [18].

According to the measurements, the total averaged particulate emissions are $309 \mathrm{mg} / \mathrm{m}^{3}$ directly behind the boilers. The multicyclone entraps more than $70 \%$ from the particles generated during the combustion in the pre-furnace (Fig.2). The number of particles behind the multicyclone reduces from $309 \mathrm{mg} / \mathrm{nm}^{3}$ down to $90 \mathrm{mg} / \mathrm{nm}^{3}$.

Further decrease of the particulate matter is obtained in the flue gas condenser, where about $7 \%$ of the particles initially originated during the combustion are trapped. Due to that the total amount of particulate matter emitted into the atmosphere consists of $68 \mathrm{mg} / \mathrm{nm}^{3}$ or $22 \%$ from the particles coming out from the boilers (Fig.2). The comparison between the actual emissions and the maximum allowed emissions shows that the boiler emits $88 \%$ from the maximum allowed $\mathrm{PM}_{10}$ particulate matter emissions.

Assuming that only coarse fly ash is trapped in the multicyclone, the proportion of the fine fly ash from the grate fired boiler is about $30 \%$.

\section{District heating plant "Zasulauks"}

The water heating boiler with the nominal capacity $20 \mathrm{MW}$ equipped with bubbling fluidized-bed furnace has been installed in 2013 in district heating plant "Zasulauks".

The water heating boiler is equipped with the electrostatic precipitator and the flue gas condenser (Fig.3). The measurements to evaluate the particle abatement from this boiler have been carried out in three places - directly behind

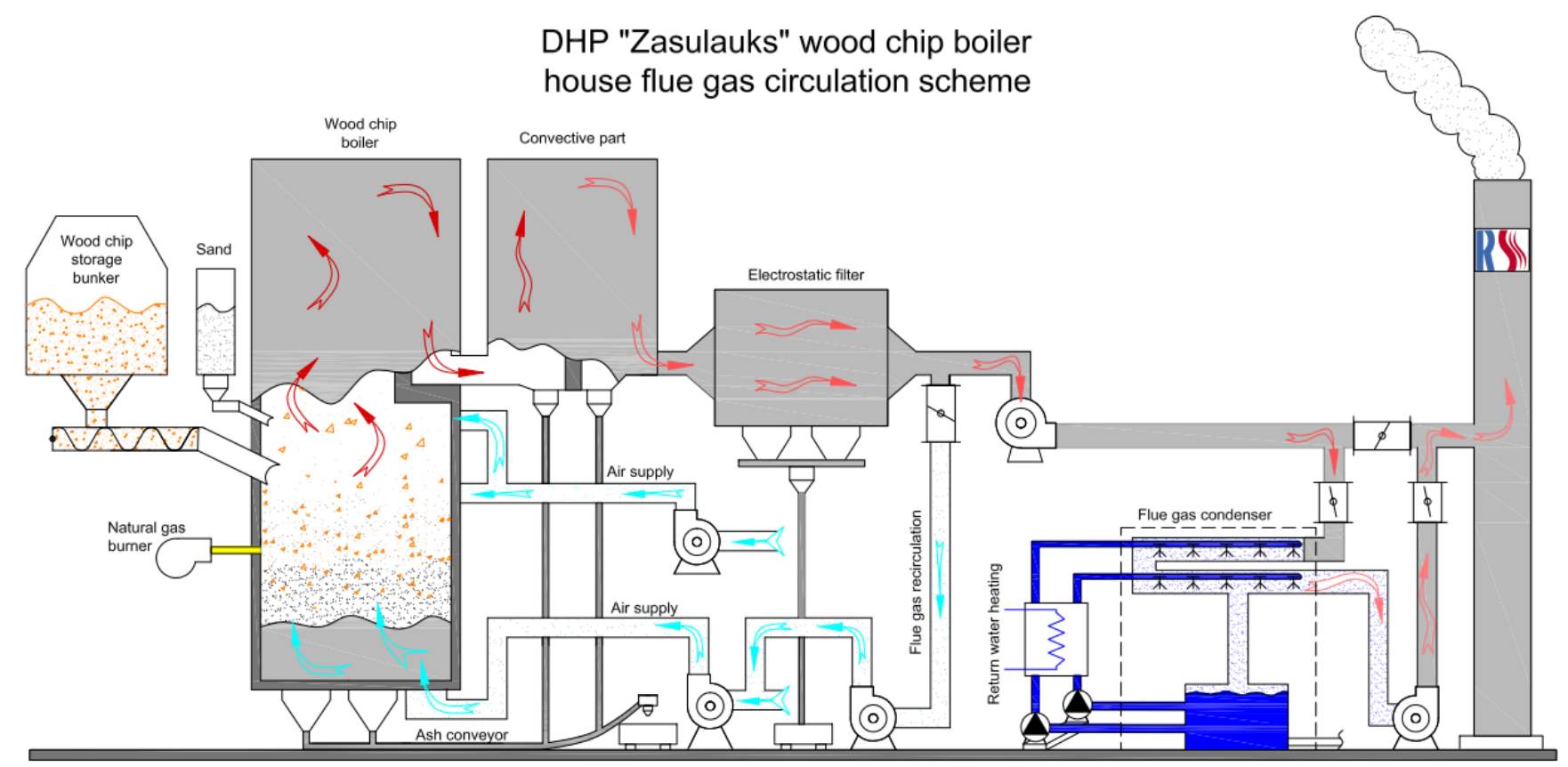

Fig. 3. Flue gas circulation scheme at DHP "Zasulauks". 
the boiler, at the exit of the electrostatic precipitator and between the flue gas condenser and the stack.

The measurements carried out behind the convective part of the boiler show that the amount of particles originated during combustion in the fluidized bed reaches $297 \mathrm{mg} / \mathrm{nm}^{3}$. After leaving the boiler, flue gases enter into the electrostatic precipitator where the amount of the particulate matter has been decreased by $85 \%$, from $297 \mathrm{mg} / \mathrm{nm}^{3}$ down to $42 \mathrm{mg} / \mathrm{nm}^{3}$ (Fig. 4). After leaving the electrostatic precipitator, the flue gases enter into the flue gas condenser primarily designed for the increase of the boiler plant efficiency. Only small amount, i.e. about $3.3 \%$ from the initially originated amount of particles, is trapped there. The final amount of particles leaving the boiler plant is $32.4 \mathrm{mg} / \mathrm{nm}^{3}$ or $10.9 \%$ (Fig. 4).

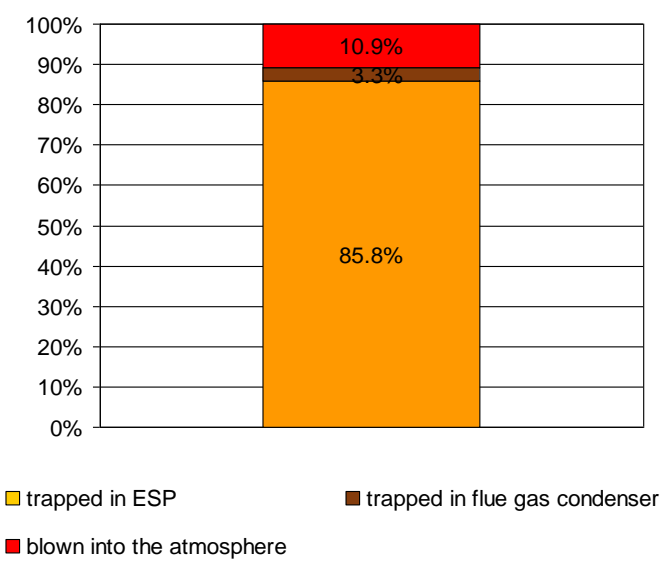

Fig. 4. Particulate matter originated in the biomass boilers at DHP "Zasulauks" trapping distribution in the flue gas cleaning devices.

The maximum limit for solid particle emission from the district heating plants "Zasulauks" is calculated to be 84 $\mathrm{mg} / \mathrm{m}^{3}$. The allowed maximum amount for particulate emissions $\mathrm{PM}_{10}$ is set $29 \mathrm{mg} / \mathrm{nm}^{3}$, while the maximum for $\mathrm{PM}_{2.5}$ is $18 \mathrm{mg} / \mathrm{nm}^{3}[19]$.

In fact, the total amount of particulates leaving the boiler plant is less than $40 \%$ of the maximum allowed particulate matter emissions.

\section{District heating plant "Ziepniekkalns"}

Biomass cogeneration steam boiler plant with installed heat capacity up to $22 \mathrm{MW}$ and electrical capacity $4 \mathrm{MW}$ is in operation since 2013. The pre-furnace for biomass combustion is designed with rotating water-cooled grates. Tangentially supplied secondary and tertiary air provides stable and complete combustion process. The boiler is equipped with two economizers to ensure higher total boiler plant efficiency by preheating supply water and air for combustion.

After passing the economizers, flue gases enter into the gas cleaning system consisting of several steps. Firstly, they flow through the multicyclone and then through the electrostatic precipitator. The flue gas condenser is installed between the electrostatic precipitator and the stack (Fig. 5).

The measurements have been carried out at the exit of the boiler, behind the multicyclone, behind the electrostatic precipitator and between the flue gas condenser and the stack.

The total amount of particles originated from the fuel in the combustion zone is $293 \mathrm{mg} / \mathrm{m}^{3}$. The amount of particulate matter is gradually decreasing when passing through the flue gas treatment devices. After leaving the boiler, the coarse dust particles are separated from the flue gas in the multicyclone. About $184 \mathrm{mg} / \mathrm{nm}^{3}$ or $63 \%$ of the particulate matter originated during the combustion is trapped there. Then flue gases enter into the electrostatic precipitator, where the amount of particulate matter is decreased down to $62 \mathrm{mg} / \mathrm{nm}^{3}$. After cleaning, the flue gases are condensed in the flue gas condenser where about $26 \mathrm{mg} / \mathrm{nm}^{3}$ of the solid particles are trapped.

\section{DHP "Ziepniekkalns" wood chip boiler house flue gas circulation scheme}

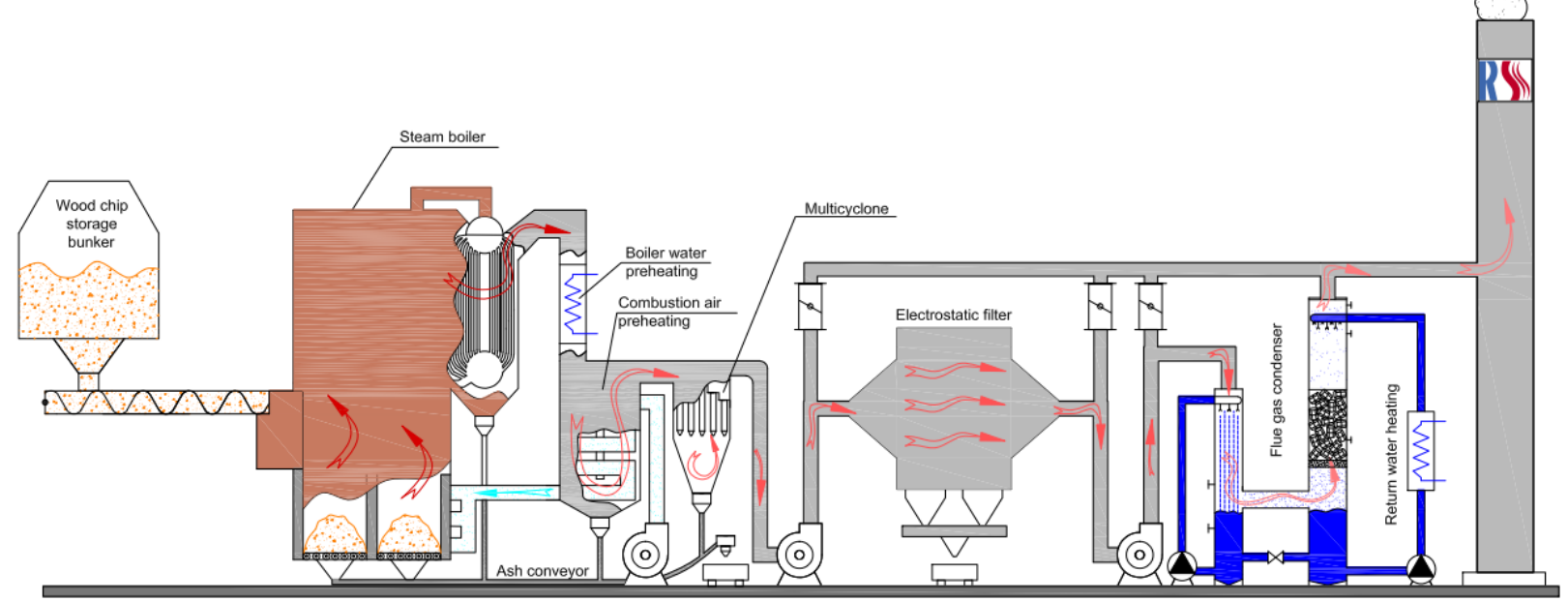

Fig. 5. Flue gas circulation scheme at DHP "Ziepniekkalns" 


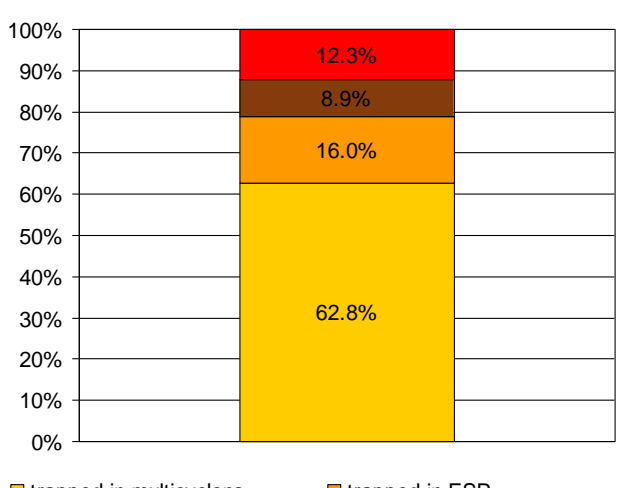

$\square$ trapped in multicyclons $\quad \square$ trapped in ESP

$\square$ trapped in flue gas condenser $\square$ blown into the atmosphere

Fig. 6. Particulate matter originated in the biomass boilers at DHP

"Zasulauks" trapping distribution in the flue gas cleaning devices.

Consequently, the total amount of the particulate matter emitted into the atmosphere is $36 \mathrm{mg} / \mathrm{nm}^{3}$ or only $12 \%$ from the emissions initially originated from the biomass combustion (Fig. 6). For the biomass boiler located in the district heating plant "Ziepniekkalns", the limit for the total amount of particulates is set at $83 \mathrm{mg} / \mathrm{nm}^{3}$. The limits for $\mathrm{PM}_{10}$ and $\mathrm{PM}_{2.5}$ are set at $58 \mathrm{mg} / \mathrm{nm}^{3}$ and $42 \mathrm{mg} / \mathrm{nm}^{3}$ correspondingly [20]. The particles emitted into the atmosphere constitute only $43 \%$ from the limits set by the environmental protection authority.

\section{V.CONCLUSIONS}

Ash characteristics and the behaviour vary depending on the biomass chemical composition, combustion appliances and combustion conditions. The major part of the biomass ashes leaves the combustion device in the form of bottom ash. A small portion of the ash travelling through the boiler with flue gases is called fly ash. The coarse fraction of the fly ash is entrained from the fuel bed. The fine fraction of the fly ash is formed by the inorganic elements and is released into the gas during combustion.

Measurements of the amount of fly ash particles from different types of biomass boilers operated at DHC "Rigas siltums" have been carried out at full load and stable operation during the heating season.

The measurement data show comparatively similar solid particle amount originated during the combustion independently from the furnace design. It allows concluding that the combustion technology is not the determinant factor for the solid particle formation if the optimal combustion conditions are provided in the furnace and there are no significant variations in the composition of wood biomass.

In order to decrease the particulate matter emitted into the atmosphere from the industrial-scale boiler, the proper flue gas treatment from the particles should be considered and appropriate equipment should be installed.

The particulate matter can be efficiently trapped from the flue gases by the particle abatement technologies. The actual emissions could constitute about $40 \%$ from the limits set by the environmental protection authority and about $9 \%$ from the limits stated by Latvian law [17].
The electrostatic precipitator with large collection surfaces is able to provide sufficient flue gas treatment from the particulate matter in the biomass boilers also without flue gas pre-treatment.

The selection of the appropriate particle abatement technology for biomass boilers can not be underestimated.

\section{REFERENCES}

[1] P. Neuenschwander, J. Good, and T. Nussbaumer Combustion efficiency in biomass furnaces with flue gas condensation, Biomass for Energy and Industry, 10th European Conference and Technology Exhibition June 811 1998, Würzburg (Germany), http://www.etsi.org. [Accessed: Aug. 17, 1998].

[2] T. Nussbaumer T., Overview on Technologies for Biomass Combustion and Emission Levels of Particulate Matter, Swiss Federal Office for the Environment (FOEN), Zürich, June 2010, pp.1-79.

[3] The assessment of flue gas particulate abatement in wood burning boilers. Report for Forestry Commission Scotland. Ref: AEA/ED56285/Issue Number 1

[4] Combating Particulate Emissions in Energy Generation and Industry, Views and Conclusions from the FINE Particles - Technology, Environment and Health Technology Programme, Ed. by Peter Herring, Tekes, 2006

[5] I.Obernberger, Reached developments of biomass combustion technolog ies and future outlook, 17th European Biomass Conference and Exhibiti on, 29 June - 3 July 2009, Hamburg, Germany.

[6] K.Carlsson, gas cleaning in flue gas from combustion of biomass, Thermal Net, Deliverable 2E-3, Intelligent Energy Europe, 2008

[7] L.Johansson, Characterisation of Particle Emissions from Small-Scale Biomass Combustion, Thesis for a degree of licentiate of engineering, Chalmers Univeristy of Technology, Goteborg, Sweden, 2002

[8] O.Sippula, Fine Particle Formation And Emissions In Biomass Combust ion, Academic dissertation,University of Eastern Finland, Kuopio 2010

[9] T.Brunner, I.Obernberger, M.Jöller, A. Arich, P.Pölt, Behavoiur of ash forming compounds in biomass furnaces-measurement and analyses of aerosols formed during fixed-bed biomass combustion, International Seminar in Zurich (Switzerland) organised on behalf of International Energy Agency (IEA) Bioenergy Task 32: Biomass Combustion and Cofiring, and the Swiss Federal Office of Energy, June 27, 2001

[10] M.Strand., J.Pagels, A.Szpila, A.Gudmundsson, E Swietlicki, M.Bohgrd, A.Sanati, Fly Ash Penetration through Electrostatic Precipitator and Flue Gas Condenser in a $6 \mathrm{MW}$ Biomass Fired Boiler, Energy \& Fuels 16, 2002, 1499-1506. http://dx.doi.org/10.1021/ef020076b

[11] O.Sippula, J.Hokkinen, H.Puustinen, P.Yli-Pirila, J.Jokiniemi, Particle emissions from small Wood-Fired Distrcit Heating Units. Energy \&Fuels 23, 2009, 2974-2982. http://dx.doi.org/10.1021/ef900098v

[12] F.Biedermann, I.Obernberger, Ash-related Problems during Biomass Combustion and Possibilities for a Sustainable Ash Utilisation, Preceedings of the International Conference "World Renewable Energy Congress” (WREC), Aberdeen, Scotland, Elsevier Ltd, Oxford, UK May, 2005,.

[13] M.Obaidullah, S.Bram, V.K.Verma, J.De Ruyck, A Review on Particle Emissions from Small Scale Biomass Combustion, International Jouranl of Renewable Energy Research, Vol.2, No.1, 2012

[14] F.Ebert, Particle separation for Biomass Combustion, Aerosols from Biomass Combustion, International Seminar in Zurich (Switzerland) organised on behalf of International Energy Agency (IEA) BioenergyTask 32: Biomass Combustion and Cofiring, and the Swiss Federal Office of Energy, June 27, 2001.

[15] O.Sippula, J.Hokkinen, H.Puustinen, P.Yli-Pirila, J.Jokiniemi, Comparison of Particle Emissions from Small Heavy Fuel Oil and Wood-Fired Boiler, Atmospheric Environment Vol.43, 2009, 4855-4864 http://dx.doi.org/10.1016/j.atmosenv.2009.07.022

[16] O.Sippula, K.Hytonen, J.Tissari, T.Raunemaa, J.Jokiniemi, Effect of Wood Fuel on the Emissions from a Top-Feed Stove, Energy \&Fuels, 21 2007, 1151-1160 http://dx.doi.org/10.1021/ef060286e

[17] Ministru kabineta noteikumi Nr.187 Kārtība, kādā novērš, ierobežo un kontrolē gaisu piesārṇojošo vielu emisiju no sadedzināšanas iekārtām, Rīgā 2013.gada 2.aprīlī- in Latvian 
[18] LR VARAM, Valsts Vides Dienesta Lielrīgas Reǵionālā Vides Pārvalde Aț̣auja A kategorijas piesārnojojošai darbībai Nr. RI 10 IA 0005, Rīga, 06.09.2010. - in Latvian

[19] LR VARAM, Valsts Vides Dienesta Lielrīgas Reǵionālā Vides Pārvalde Ațauja A kategorijas piesārṇojošai darbībai Nr. RI12IA0001, Rīga, 23.01.2012. - in Latvian

[20] LR VARAM, Valsts Vides Dienesta Lielrīgas Reǵionālā Vides Pārvalde Aț̣auja A kategorijas piesārṇojošai darbībai Nr. RI12IA0006, Rīga, 21.12.2012. - in Latvian 